\title{
A Comparative Study of the Effects of Ethanolic Extract of Sesamum indicum Seeds and Mesterolone on Some Testicular Morphometry of Adult Male Wistar Rats Secondary to Ketoconazole-Induced Damage
}

\author{
Yusuf $\mathrm{MK}^{1 *}$, Ibegbu AO ${ }^{1}$, Alawa $\mathrm{JN}^{1}$ \\ ${ }^{1}$ Department of Human Anatomy, Faculty of Basic Medical Sciences, College of Medical Sciences, Ahmadu \\ Bello University, Zaria-Nigeria.
}

\begin{abstract}
*Corresponding Author: Yusuf MK, Department of Human Anatomy, Faculty of Basic Medical Sciences, College of Medical Sciences, Ahmadu Bello University, Zaria-Nigeria. E-mail: maylkabiru2008@yahoo.com; maylkabiru2014@gmail.com
\end{abstract}

Received Date: 08-04-2020; Accepted Date: 22-04-2020; Published Date: 30-04-2020

Copyright $^{\oplus} 2020$ by Yusuf MK, et al. All rights reserved under CC BY-NC-ND. This is an open access article distributed under the terms of the Creative Commons Attribution License, which provides freedom to read, share, copy and redistribution of material in any of the medium, provided with the original author and source are credited.

\begin{abstract}
Aim: The study aimed at comparing the effects of ethanolic extract of Sesamum indicum seeds with mesterolone on some testicular morphometry following ketoconazole induced damage in Wistar rats.

Methods: Thirty-six (36) adult male Wistar rats were divided into six (6) groups of six rats each. Groups 1,2,3,4,5 and 6 were administered $1 \mathrm{ml}$ of normal saline, $100 \mathrm{mg} / \mathrm{kg}$ body weight (bwt) of Ketoconazole only, $500 \mathrm{mg} / \mathrm{kg}$ bwt of Ethanolic Extract of Sesamum indicum (EESI) seeds then $100 \mathrm{mg} / \mathrm{kg}$ bwt of Ketoconazole, $100 \mathrm{mg} / \mathrm{kg}$ bwt of Ketoconazole then $250 \mathrm{mg} / \mathrm{kg}$ body weight of EESI seeds, $100 \mathrm{mg} / \mathrm{kg}$ bwt of Ketoconazole then $500 \mathrm{mg} / \mathrm{kg}$ bwt of EESI, 100 $\mathrm{mg} / \mathrm{kg}$ body weight of Ketoconazole, respectively. All administrations were carried out orally and once per day. The histological slides were prepared for morphometric analyses. Results: No observed significant differences in the morphometry of the groups administered EESI and Mesterolone. However, the morphometry of the group administered EESIS and Mesterolone were significantly increased when compared with group 2 alone $(\mathrm{P} \leq 0.05)$. Conclusions: The effects of the administration of ethanolic extract of Sesamum indicum seeds on the morphometry of the testis appeared to be indifferent with Mesterolone; and both EESIS.


Mesterolone also appeared to have minimize the distortion of the normal dimensions of the testis caused by ketoconazole which may be due to their androgenic properties.

\section{Keywords}

Evaluation; Sesamum; Morphometry; Testicular; Ketoconazole; Rats

\section{Introduction}

Adverse effects of drugs among other factors are known to affect normal body functions and most especially reproductive health [1]. One of such drugs is Ketoconazole, an antifungal drug [2].

Ketoconazole is packaged pharmaceutically in the form of tablets, creams and injections and has been reported to inhibit the stimulation of testicular testosterone production by Human Chorionic Gonadotropin (HCG) in a dose dependent manner [3]. Steroids such as dihydrotestosterone and estradiol are equally, selectively displaced from serum-binding globulin by ketoconazole [4]. The suppression of testicular testosterone synthesis and the displacement of oestrogen from sex hormone binding globulin may decrease the androgen/oestrogen ratio of the blood and contributes to the development of gynaecomastia that has being reported in some ketoconazole treated patients [4]. Administration of ketoconazole alters sperm indices.

Over the years, there has been increased scientific research to minimize the health hazards potentiated by some toxins and this was done on phytochemicals extracted from plant species [5]. In an effort to stem the contraindications of some of these synthesized drugs, plant medicine (phyto-medicine) has been used as alternatives in many parts of Africa and the rest of the world [6].

One of such phyto-medicine is Sesame indicum. Sesame seeds are reported to contain high level of unsaturated fatty acids such as Oleic acid-38.84\% and linolenic acid-46.26\% [6]. Trace elements such as Calcium, Iron, Magnesium, Zinc, Copper and Phosphorous were also reported to be contained in it [7]. Sesame seeds are also reported to be rich in phyto estrogenic lignans which is an important phytochemical known to man [8].The entire sesame plant is very valuable and serves as staple food in most ethnic groups in North-Central and South-Western part of Nigeria [8]. 


\section{Materials and Method}

\section{Seed procurement and identification}

Amount of $470 \mathrm{~g}$ of Sesamum indicum seeds were obtained from Samaru market- Zaria, Kaduna State, Nigeria and authenticated in the herbarium of the Department of Biological Sciences, Ahmadu Bello University Zaria and assigned voucher no. 4. The seeds were macerated using $95 \%$ ethanol to obtain the extract with a yield weight of $46.42 \mathrm{~g}$ in solvent form.

\section{Drugs and Reagents}

Two hundred (200) $\mathrm{mg}$ of ketoconazole tablets and $25 \mathrm{mg}$ of Tablet Provirone (Mesterolone) manufactured by Divine New Favour Pharmaceuticals (Anambra State) and Bayers Pharmaceuticals (United Kingdom) with batch Nos. 82339737 and 4008500060056 and NAFDAC Nos. A4-2186 and 04-1300, respectively, were purchased from Micro novo Pharmaceutical Company Plc. Kano, Kano State, Nigeria.

\section{Methods}

\section{Extraction of Sesame Seeds}

Amount of four hundred and seventy (470) $\mathrm{g}$ of sesame seed was macerated in a maceration apparatus. The sesame seeds were poured into $2 \mathrm{ml}$ maceration apparatus (Pyrex) and the seeds coats were manually removed. The macerated seeds were later transferred into a three and half (3.5) lt beaker containing $95 \% \mathrm{v} / \mathrm{v}$ of ethanol to cause the removal of flavanoids and lignans. It was stirred and left for six hours to allow the extraction of polar substances. The supernatant was sieved off using a metallic sieve and the filtrate was collected into a separate beaker. The filtrate was collected into an evaporating dish with the use of a spatula and placed on a water bath, heated to a temperature of $60^{\circ} \mathrm{C}$ to completely remove the ethanol. The extract was kept for eighteen hours to allow for evaporation to take place. The yield weight of the extract was $46.42 \mathrm{~g}$ in solvent form.

\section{Experimental Procedure}

The $\mathrm{LD}_{50}$ the ethanolic extract of Sesamum indicum seeds in wistar rats was researched and found to be above $5000 \mathrm{mg} / \mathrm{kg}$ bwt meaning that the extract is safe.

The equivalent dose of the drugs and the sesame seed extract; in ml (milliliters) were derived using the formulae: 
Volume $(\mathrm{ml})=\underline{\text { Dose } \times \text { weight }(\mathrm{kg})}$

Stock concentration

The equivalent dose in $\mathrm{ml}$ of ethanolic extract of Sesamum indicum seeds was calculated as follows: $500 \mathrm{mg} / \mathrm{kg} \mathrm{bwt}=500 \mathrm{mg}=1000 \mathrm{~g}$, the average weights of the rats at the time of commencement of the experiment was $180 \mathrm{~g}$; therefore, the administrable dose (x) for a rat that weighed $180 \mathrm{~g}$ was calculated as:

Volume $=\underline{500 \mathrm{mg} / \mathrm{kg} \times 0.180 \mathrm{~kg}}$ $128.3 \mathrm{mg} / \mathrm{ml}$

$0.70 \mathrm{ml}$ was obtained as the volume for a dose of $500 \mathrm{mg} / \mathrm{kg}$ bwt which was the high dose group. Similar method was used to calculate the volume of the low dose group $(250 \mathrm{mg} / \mathrm{kg}$ bwt) and the value $0.35 \mathrm{ml}$ was obtained. Tablet mesterolone was prepared as $25 \mathrm{mg}$ and it was the recommended dose for an adult person (Average weight $=70 \mathrm{~kg}$ ).

From above, the administrable dose per $1 \mathrm{~kg}$ was calculated as shown below

$25 \mathrm{mg}$ (mesterolone) $=70 \mathrm{~kg}=70000 \mathrm{~g}$; therefore, the dose $(\mathrm{x})$ for every $1 \mathrm{~kg}=1000 \mathrm{~g}$ is calculated as follows:

$\mathrm{x}=\underline{25 \mathrm{mg} \times 1,000}=0.36 \mathrm{mg} / \mathrm{kg} \mathrm{bwt}$ 70,000

From above, the administered dose for a rat that weighed $180 \mathrm{~g}$ was calculated as:

$\underline{0.36 \mathrm{mg} \times 180 \mathrm{~g}=0.065 \mathrm{mg}}$

$1000 \mathrm{~g}$

Earlier, it was stated that the packaged form of mesterolone is $25 \mathrm{mg}$ per tablet.

The tablet was dissolved in $10 \mathrm{ml}$ of distilled water to obtain a concentration of $2.5 \mathrm{mg} / \mathrm{ml}$. from above, $2.5 \mathrm{mg}$ is contained in $1 \mathrm{ml}$, $\mathrm{m} \mathrm{ml}$ will contain $0.065 \mathrm{mg}$. By calculation,

$\mathrm{X}=0.065 / 2.5=0.026 \mathrm{ml}$, therefore, $0.026 \mathrm{ml}$ which contains $0.065 \mathrm{mg}$ of mesterolone tablet was measured using a micropipette and was administered to the rats.

\section{Animal Sacrifice}

The animals were put to death via perfusion technique, the left testis was excised and immersed in a solution of $10 \%$ formalin and prepared histologically for the determination testicular morphometric parameters. 


\section{Statistical Analysis}

All data obtained were expressed as mean \pm Standard Error of Mean, (SEM). One way Analysis of Variance (ANOVA) was used to compare the mean difference between and within the groups and a P-value of $\leq 0.05$ was considered statistically significant, a post-Hoc was carried out to indicate were significant difference lie. Statistical analysis was carried out using Statistical Package for Service Solution (SPSS) Version 20.

\section{Morphometric Analyses}

\section{Luminal and Epithelial Dimensions of the Seminiferous Tubules}

The longitudinal and transverse dimensions of the lumen of the seminineferous tubules were measured with an ocular micrometer and a stage micrometer. The ocular micrometer made up of vertical and horizontal grid lines was inserted in $a \times 400$ objective lens and aligned with the calibrated stage micrometer. The length of the un-calibrated ocular micrometer was estimated from that of the stage micrometer after alignment. The stage micrometer was replaced with slides containing tissue sections and the luminal dimensions were obtained from the estimated distances on the ocular micrometer. The part of the lumen of the seminiferous tubule that corresponded with the horizontal axis of the grid line on the ocular micrometer was considered as the transverse dimension and the part that corresponded with the vertical axis was considered as the longitudinal dimension. The same procedure was used in measuring the epithelial height as shown in Fig. 1. The height of the epithelium of each seminiferous tubule was determined with an occcular micrometer and the mean for each group was obtained, Fig. 2-7.

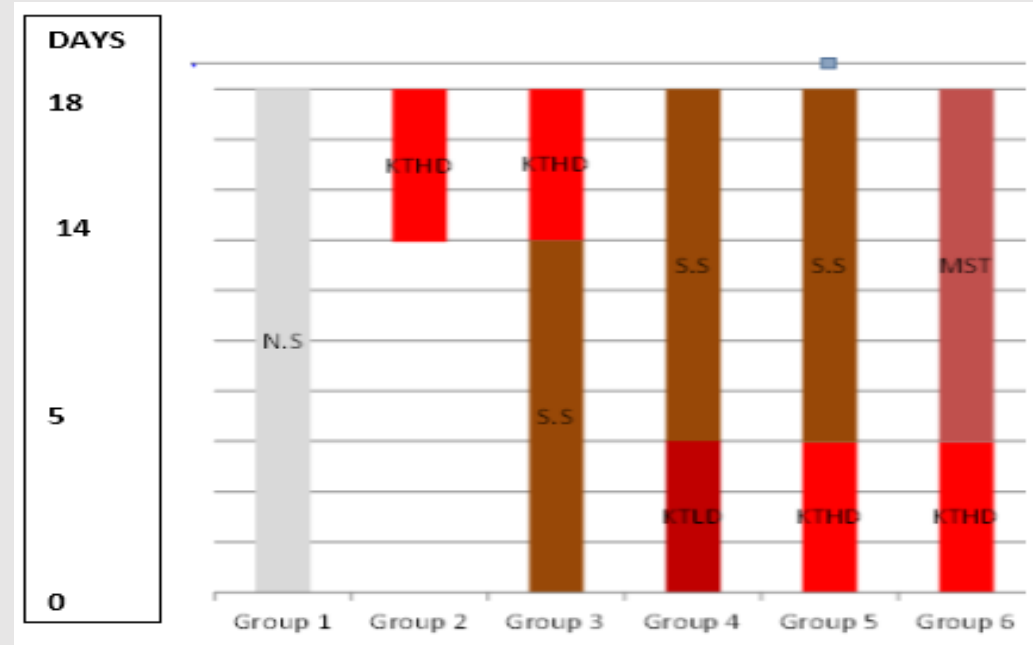

Figure 1: Histogram representing drug administration.

(NS: Normal Saline, KTHD: Ketoconazole High Dose, SS: Sesamum Seeds, KTLD:

Ketoconazole Low Dose Group, MST: Mesterolone). 


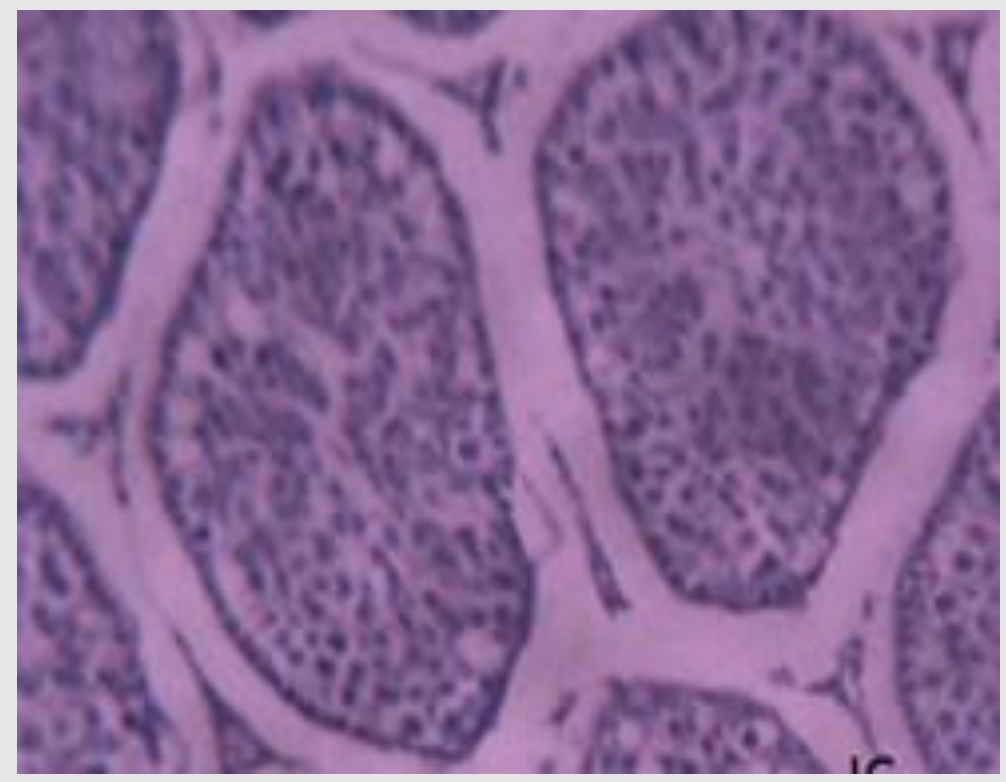

Figure 2: A section of the testis obtained from group 1. (Arrow indicates luminal dimensions (Longitudinal dimension LD; $2.75 \mu \mathrm{m}$, Transverse dimension LD; $2.92 \mu \mathrm{m}$ and epithelial height EH $2.92 \mu \mathrm{m}$ (Masson Trichrome stain $\times 250$ ).

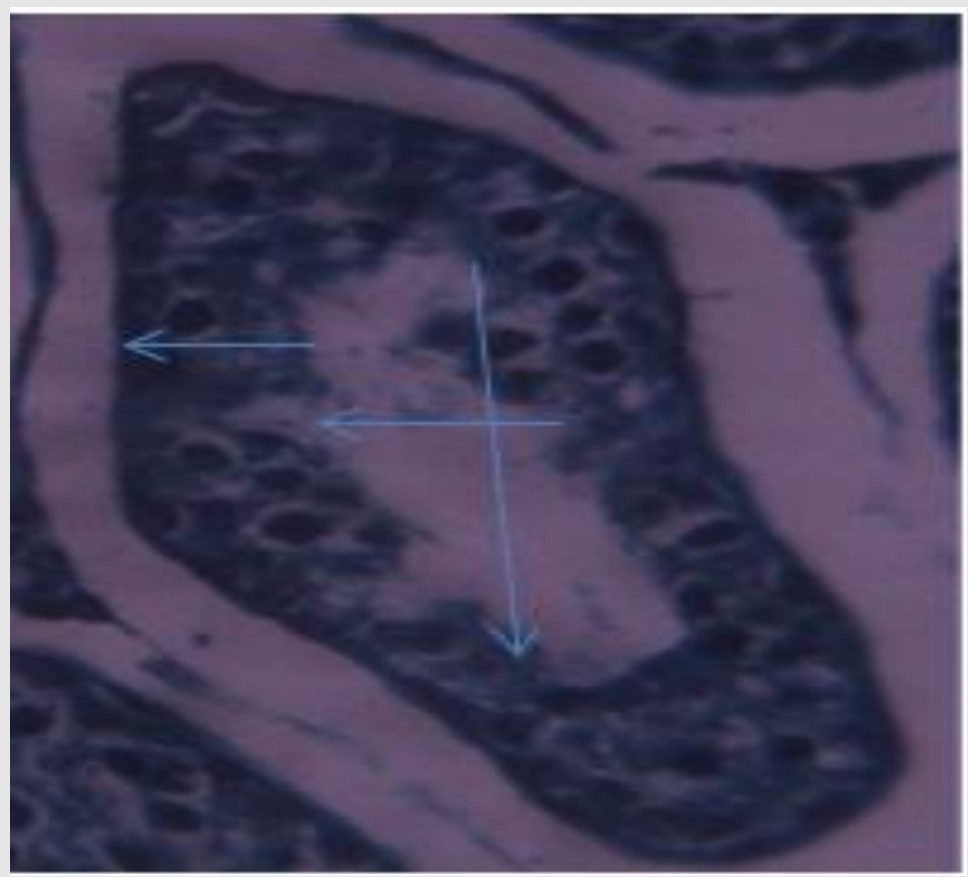

Figure 3: A section of the testis obtained from group 2. (Longitudinal dimension LD; 6.17 $\mu \mathrm{m}$, Transverse dimension LD; $4.83 \mu \mathrm{m}$ and epithelial height EH $2.92 \mu \mathrm{m}$ (Masson Trichrome stain $\times 250$ ). 


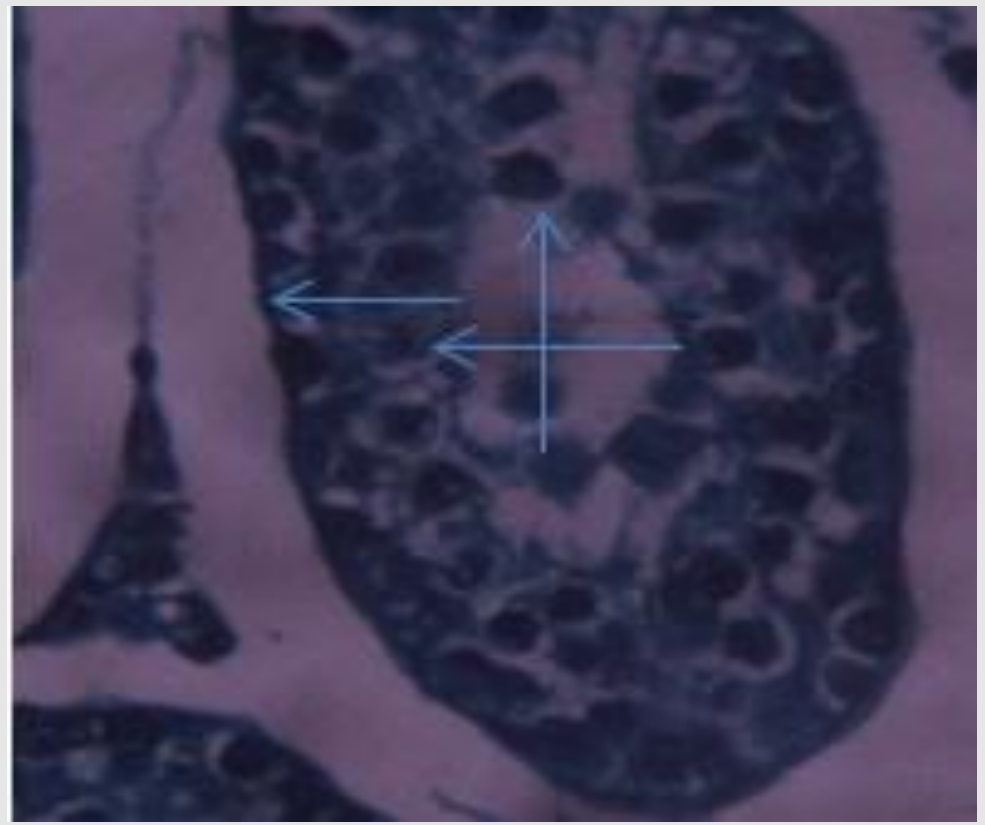

Figure 4: A section of the testis obtained from group 3. (Longitudinal dimension LD; 2.00 $\mu \mathrm{m}$, Transverse dimension LD; $8.17 \mu \mathrm{m}$ and epithelial height EH $2.92 \mu \mathrm{m}$ (Masson Trichrome stain $\times 250$ ).

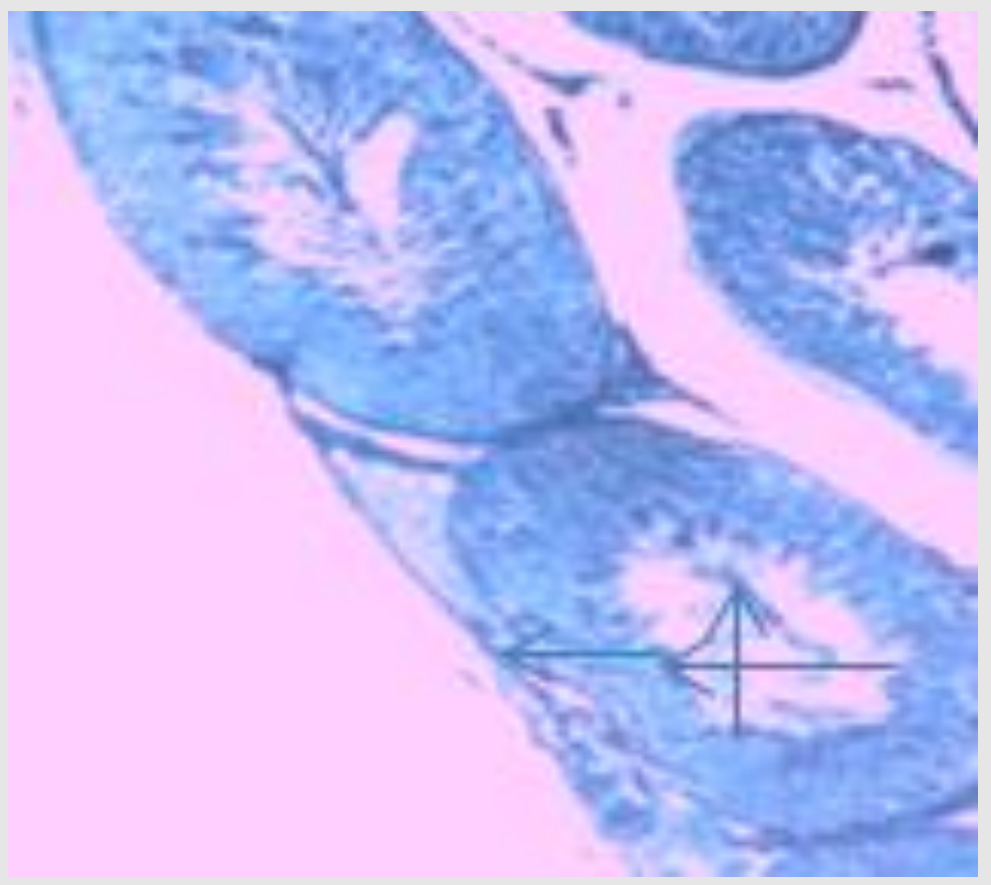

Figure 5: A section of the testis obtained from group 4. (Longitudinal dimension LD; 4.33 $\mu \mathrm{m}$, Transverse dimension LD; $7.00 \mu \mathrm{m}$ and epithelial height EH $2.92 \mu \mathrm{m}$ (Masson Trichrome stain $\times 250$ ). 


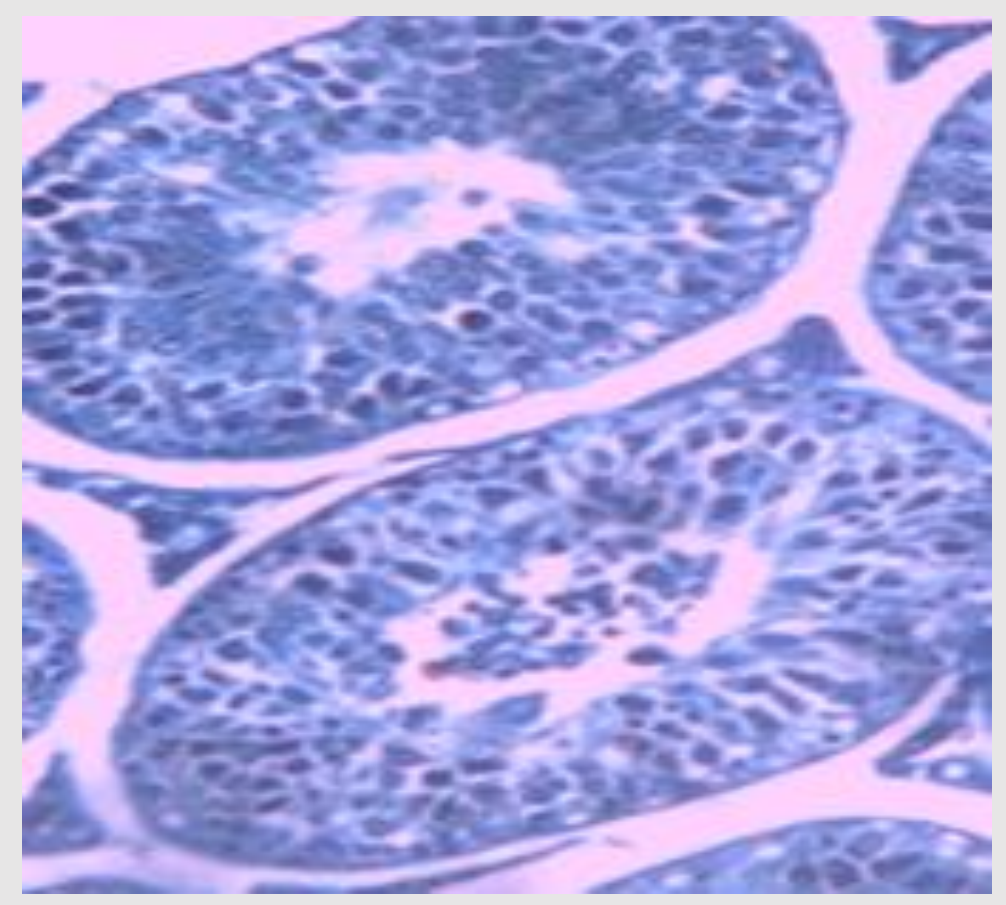

Figure 6: A section of the testis obtained from group 5. (Longitudinal dimension LD; 3.92 $\mu \mathrm{m}$, Transverse dimension LD; $4.17 \mu \mathrm{m}$ and epithelial height EH $2.92 \mu \mathrm{m}$ (Masson Trichrome stain $\times 250$ ).

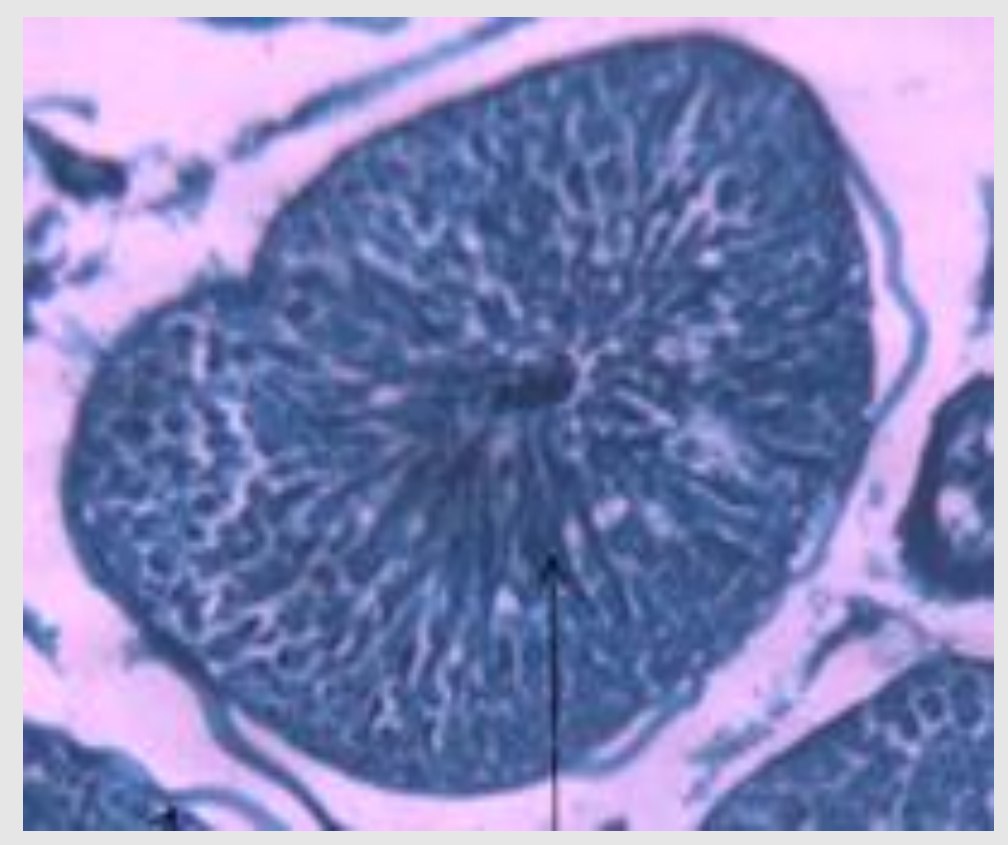

Figure 7: A section of the testis obtained from group 6. (Longitudinal dimension LD; 3.67 $\mu \mathrm{m}$, Transverse dimension LD; $6.75 \mu \mathrm{m}$ and epithelial height EH $2.92 \mu \mathrm{m}$ (Masson Trichrome stain $\times 250$ ).

Yusuf MK | Volume 1; Issue 1 (2020) | JCMR-1(1)-007 | Research Article

Citation: Yusuf MK, et al. A Comparative Study of the Effects of Ethanolic Extract of Sesamum indicum Seeds and Mesterolone on Some Testicular Morphometry of Adult Male Wistar Rats Secondary to Ketoconazole-Induced Damage. Jour Clin Med Res. 2020;1(1):1-12. 


\section{Results}

\section{Luminal Dimensions}

The results of the transverse dimension of the lumen of the seminiferous tubules of the testes are shown in Table 1 and 2. It was observed that no significant differences in the transverse dimension of the lumen of the testis exist between group 2 and groups 5 and 6 respectively. No observed significant difference between groups 5 and 6. However, groups 1 and 2 were observed to be significantly increased when compared with group 3.

\begin{tabular}{|l|l|l|}
\hline S/N & Groups & Dosage/Duration of Administration \\
\hline 1 & Negative Control & $1 \mathrm{ml}$ of Normal Saline daily for the experimental period. \\
\hline 2 & Positive Control & $\begin{array}{l}\text { Ketoconazole }(100 \mathrm{mg} / \mathrm{kg} \text { bwt) once daily for five (5) days } \\
\left(14^{\text {th }}-18^{\text {th }} \text { day of experiment). }\right.\end{array}$ \\
\hline 3 & Prophylactic Group & $\begin{array}{l}500 \mathrm{mg} / \mathrm{kg} \text { bwt of ethanolic extract of Sesame indicum } \\
\text { seeds for }(13 \text { days })+100 \mathrm{mg} / \mathrm{kg} \text { bwt of ketoconazole for } \\
(5) \text { five days. }\end{array}$ \\
\hline 4 & $\begin{array}{l}\text { Therapeutic Low Dose } \\
\text { Group }\end{array}$ & $\begin{array}{l}100 \mathrm{mg} / \mathrm{kg} \text { bwt of Ketoconazole for (5) five days }+250 \\
\mathrm{mg} / \mathrm{kg} \text { bwt of ethanolic extract of sesame indicum seeds } \\
\text { once daily for five (5) days and thirteen (13) days } \\
\text { respectively. }\end{array}$ \\
\hline 5 & $\begin{array}{l}\text { Therapeutic High Dose } \\
\text { Group }\end{array}$ & $\begin{array}{l}100 \mathrm{mg} / \mathrm{kg} \text { bwt of Ketoconazole for (5) five days }+500 \\
\mathrm{mg} / \mathrm{kg} \text { bwt of ethanolic extract of sesame indicum seeds for } \\
\text { thirteen days. }\end{array}$ \\
\hline 6 & $\begin{array}{l}\text { Ketoconazole } \\
\text { Mesterolone }\end{array}$ & $\begin{array}{l}\text { Ketoconazole (100 mg/ kg bwt) for five days }+0.36 \mathrm{mg} / \mathrm{kg} \\
\text { bwt of mesterolone once daily for thirteen days. }\end{array}$ \\
\hline
\end{tabular}

Table 1: Groups of the animals and their administrations.

(All administrations were carried out orally). 


\begin{tabular}{|c|c|c|c|c|}
\hline Group & $\mathbf{N}$ & $\begin{array}{c}\text { Transverse dimension } \\
(\boldsymbol{\mu m})\end{array}$ & $\begin{array}{c}\text { Longitudinal } \\
\text { dimension }(\boldsymbol{\mu m})\end{array}$ & $\begin{array}{c}\text { Epithelial dimension } \\
(\boldsymbol{\mu m})\end{array}$ \\
\cline { 3 - 5 } & 6 & Mean \pm SEM & Mean \pm SEM & Mean \pm SEM \\
\hline 1 & 6 & $4.58 \pm 0.27$ & $2.75 \pm 0.25$ & $2.92 \pm 0.33^{*}$ bce \\
\hline 2 & 6 & $4.58 \pm 0.37$ & $6.17 \pm 0.79 *$ de & $4.83 \pm 0.48^{*} \mathrm{~b}$ \\
\hline 3 & 6 & $1.83 \pm 0.31 * \mathrm{a}$ & $2.00 \pm 0.26^{*}$ acd & $8.17 \pm 0.65 * \mathrm{~d}$ \\
\hline 4 & 6 & $4.33 \pm 1.12$ & $4.83 \pm 0.48$ & $7.00 \pm 0.26$ \\
\hline 5 & 6 & $4.17 \pm 0.42$ & $3.92 \pm 0.33$ & $5.42 \pm 0.49$ \\
\hline 6 & 6 & $3.75 \pm 0.31$ & $3.67 \pm 0.67$ & $6.75 \pm 0.54$ \\
\hline$* a b c d e$ & $1,2,3,4,5 \& 6(\mathrm{P} \leq 0.05)$. & \\
\hline
\end{tabular}

Table 2: Indices of the seminiferous tubule of animals in the experimental groups.

\section{Epithelial Height}

The result of the study of the epithelial height of the seminiferous tubules of the testes in the experimental animals are shown in Table 2.

The result showed that, no significant difference in the epithelial height of the seminiferous tubules exist between group 2 and groups 5 and 6 . No significant difference in the epithelial height was also observed between groups 5 and $6(\mathrm{P} \leq 0.05)$. However, groups 5 and 3 were significantly increased when compared with group $2(\mathrm{P} \leq 0.05)$.

\section{Discussion}

The luminal dimension of the seminiferous tubules of the Groups treated with ethanolic extract of Sesamum indicum seeds and mesterolone (Groups 3, 4, 5 and 6) were observed to be decreased in longitudinal dimension when compared with the Group treated with ketoconazole alone (Group 2) as most of the matured sperm cells and spermatids that lined the lumen of the seminiferous tubules in the ketoconazole treated group were degenerated. Osinubu et al., (2005) had a contrasting view when they observed that certain endocrine disruptors demonstrated a continuous decrease in the mean testicular volume, diameter and cross sectional area of the seminiferous tubules [7].

The continuous decrease in mean testicular morphometry, of seminiferous epithelium in rats administered ketoconazole an endocrine disruptor, suggests that the morphology of germinal epithelium responsible for unique composition of luminal fluids is compromised. This unique composition of luminal fluid is an essential prerequisite for the process of spermatogenesis [7]. It may therefore be suggested that endocrine disruptors like ketoconazole can also compromise 
the process of spermatogenesis but the mean luminal dimension of the lumen of the seminiferous tubule did not decrease in the present research and therefore did not agree with the work of Osinubu et al., (2005). It has been reported that endocrine disruptors are wide spectrum ion blockers. This also suggests that ketoconazole disrupted the ion channel leading to the disturbance in ionic equilibrium across membrane and ultimately to a disruption or distortion in the cellular morphology. From the present study, it was observed that disruption of the tubular morphology was also accompanied by general destruction of testicular interstitium.

From the observations made, the ethanolic extract of Sesamum indicum seeds and Mesterolone have decreased the luminal dimension of the seminiferous tubules especially in the prophylactic Group (3) when compared with the Control Groups 1 and 2 and also increased the epithelial dimensions of the testes of rats in other experimental experimental Groups (5 and 6). The influence exhibited by the ethanolic extract of Sesamum indicum seeds and Mesterolone could be attributed to their antioxidant activities and enzyme (cytochrome P-450 and desmolase $17,20)$ boosting effects.

\section{Conclusion}

The morphometry of the seminiferous tubules was enhanced as the epithelial height of the seminiferous tubules in rats administered EESI before ketoconazole were significantly increased compared with rats in the Control Group 2 more so, the transverse and longitudinal dimensions of the seminiferous tubules in rats administered EESI before ketoconazole were reduced significantly when compared with rats in the Control Group 2.

\section{Significance of the Study to Humans}

Scientific research has proved that the DNA composition of Wister rats (Rat models) body metabolism and physiology only differs from that of humans by $0.5 \%$. This implies that, whatever result is obtained from the rat models, there is a $99.5 \%$ chance that the same result will be obtained in humans.

The results obtained from this research therefore, means that, intake of ethanolic extract of Sesamum indicum seeds in a proportionate dose $(\mathrm{mg} / \mathrm{kg}$ body weight) with what was administered to the rat models in humans medicating on ketoconazole for certain ailments can help minimise it's adverse effects as seen on the micrographs and table of testicular moephometry that was analysed. 


\section{Recommendation}

A hormonal assay should be conducted in further studies to ascertain the level of increase in testosterone.

\section{References}

1. Izegbu MC, Ojo MO, Shittu LA. Clinico-pathological patterns of testicular malignancies in Ilorin, Nigeria-a report of 8 cases. J Can Res Therap: PLOS Bio. 2005;1(4):229.

2. Amin A. Ketoconazole-induced testicular damage in rats reduced by Gentiana extract. Exp Toxicol Pathol. 2008;59(6):377-84.

3. Richard S. Male Infertility Human Sperm Morphology Fixed and stained human sperm Advanced fertility Centre of Chicago sperm pictures- Male infertility, Human sperm morphology fixed and stained human sperm pictures from the IVF lab. 2015.

4. Grosso DS, Boyden TW, Pamenter RW, Johnson DG, Stevens DA, Galgiani JN. Ketoconazole inhibition of testicular secretion of testosterone and displacement of steroid hormones from serum transport proteins.

Antimicrob Agents Chemother. 1983;23(2):207-12.

5. Bankole MA, Shittu LA, Ahmed TA, Bankole MN, Shittu RK, Terkula K, et al. Synergistic antimicrobial activities of phytoestrogens in crude extracts of two sesame species against some common pathogenic microorganisms. African J Traditional, Complement Alternative Med. 2007;4(4):427-33.

6. Nzikou JM, Matos L, Bouanga-Kalou G, Ndangui CB, Pambou-Tobi NP, Kimbonguila A, et al. Chemical composition on the seeds and oil of sesame (Sesamum indicum L.) grown in Congo-Brazzaville. Adv J Food Sci Technol. 2009;1(1):6-11.

7. Obiajunwa EI, Adebiyi FM, Omode PE. Determination of essential minerals and trace elements in Nigerian sesame seeds, using TXRF technique. Pak Journal Nutr. 2005;4(6):393-5.

8. John B, Anton JE, Alexie A, Thompso T, Chris S, Deborah SM. Human micro RNA. 2004. 